\title{
ANALISIS PENGARUH KEPUASAN PASIEN TERHADAP KUALITAS PELAYANAN RESEP DI APOTEK INSTALASI FARMASI BADAN RUMAH SAKIT DAERAH LUWUK KABUPATEN BANGGAI
}

\section{THE ANALYSIS OF PATIENT SATISFACTION IMPACT TOWARDS THE QUALITY OFPRESCRIPTION SERVICE IN DISPENSARY OF PHARMACY INSTALLATION IN PUBLICHOSPITAL OF LUWUK,BANGGAI REGENCY}

\author{
Dyah Nurfitri Maharani $^{{ }^{*}}$, Alwiyah Mukaddas ${ }^{1}$ Indriani $^{1}$ \\ ${ }^{1}$ Jurusan Farmasi, Fakultas MIPA, Universitas Tadulako, Palu, Indonesia
}

Received 22 Agustus 2016, Accepted 25 September 2016

\begin{abstract}
ABSTRAK
Apotek adalah salah satu tempat pelayanan kefarmasian dengan tujuan melakukan praktek kefarmasian oleh apoteker dan penyaluran sediaan farmasi kepada masyarakat. Salah satu indikator yang digunakan untuk mengevaluasi kualitas pelayanan di apotek adalah dengan mengukur tingkat kepuasan pelanggan. Penelitian ini bertujuan untuk mengetahui pengaruh kepuasan pasien terhadap kualitas pelayanan resep di apotek instalasi farmasi Badan Rumah Sakit Daerah Luwuk Kabupaten Banggai yang di hubungkan dengan lima dimensi kualitas pelayanan yang meliputi tangible, reliability, responsivenesess, assurance, dan empati. Penelitian ini dilakukan dengan teknik pengambilan sampel yaitu accidental sampling memakai instrument kuesioner yang menggunakan skala likert. Data dianalisis dengan metode analisis regresi linear berganda dengan jumlah responden yaitu 110 responden. Hasil penelitian terhadap 110 responden menunjukkan variable tangible, reliability, responsivenesess, assurance, dan empati berpengaruh signifikan terhadap kepuasan pasien dengan nilai signifikan 0,000 (P Value $<0,05$ ). Koefisien determinasi yang dihasilkan adalah sebesar 0,482 yang berarti kepuasan pasien terhadap kelima variabel sebesar $48,2 \%$.
\end{abstract}

Kata kunci : Apotek, Kualitas pelayanan, Kepuasan pasien

\begin{abstract}
Pharmacy is one place of the pharmaceutical care with aims to practice pharmacy by pharmacists and pharmaceutical supply distribution to the public. One of the indicators use to evaluate the quality of care in pharmacies was to measure the level of customer satisfaction. This research is aimedto find out the impact of patient satisfaction towards the quality of prescription service in dispensary of pharmacy installation in Public Hospital of Luwuk, Banggai regency which is related with five dimension of quality service, which are; tangible, reliability, responsiveness, assurance and empathy. This research was conducted used sampling method called accidental sampling using questioner with likert scale. The data was analyzed using doubled linear regression method with the total of 110 respondent. The result from these respondent showedtangible, reliability, responsiveness, Assurance and empathyvariablewhich significantly affected the satisfaction of patient, with significance score of 0,000 (P value $<0,05$ ). Determination coefficient resulted is 0,482 which mean that the satisfaction level of patient towards the five variables is $48,2 \%$.
\end{abstract}

Keywords: Pharmacy, Service quality, Patient satisfaction

*Coresponding Author : Dyah Maharani, Dyahmaharani24@gmail.com (ph : +62-852-4138-4724) 


\section{PENDAHULUAN}

Pelayanan kefarmasian merupakan salah satu usaha yang dapat digunakan untuk mewujudkan kesejahteraan masyarakat. Masyarakat mengharapkan pelayanan farmasi yang sebaik mungkin dalam proses penyaluran obat (Azwar, 1996).

Instalasi farmasi rumah sakit merupakan suatu bagian dari fasilitas di rumah sakit, yaitu tempat penyelenggaraan semua kegiatan pekerjaan kefarmasian yang ditujukan untuk keperluan rumah sakit itu sendiri. Salah satu bagian dari instalasi farmasi rumah sakit adalah apotek rumah sakit, yaitu tempat tertentu, tempat dilakukan pekerjaan kefarmasian dan penyaluran obat kepada masyarakat (Siregar, 2003).

Pelayanan apotek rumah sakit diperlukan oleh masyarakat untuk memberikan jaminan pengobatan rasional (efektif, aman, tersedia, dan biaya terjangkau). Selain itu juga diperlukan pelayanan yang berkualitas agar dapat memuaskan masyarakat sebagai konsumen (Aditama, 2002). Kualitas jasa pelayanan merupakan bagian penting yang perlu mendapat perhatian dari pihak manajemen rumah sakit untuk peningkatan kualitas apotek rumah sakit, oleh karena itu, dengan adanya kualitas pelayanan yang baik maka kepuasan pasien dapat terpenuhi (Ardian A, 2001)

Hasil penelitian yang dilakukan oleh Gary (2012) menunjukkan bahwa nilai koefisien terhadap kepuasan pasien sebesar 52,7\%. Dimensi yang memiliki pengaruh yang signifikan terhadap kepuasan pasien yaitu dimensi Tangible 0,004, Reliability 0,000, Assurance 0,001, sedangakan dimensi yang tidak memiliki pengaruh yang signifikan terhadap kepuasan pasien yaitu Responsivenesess 0,134 dan Empati 0,191.

Badan Rumah Sakit Daerah Luwuk merupakan satu-satunya rumah sakit umum milik Pemerintah Daerah Kabupaten Banggai. Badan rumah sakit ini menjadi rumah sakit rujukan bagi setiap puskesmas yang ada di wilayah Kabupaten Banggai. Pelayanan resep diinstalasi farmasi rumah sakit merupakan unsur penting di rumah sakit ini. Instalasi Farmasi Badan Rumah Sakit Daerah Luwuk melayani resep untuk pasien rawat jalan dan rawat inap, Banyaknya permintaan obat oleh pasien rawat jalan dan rawat inap tentunya pihak rumah sakit dituntut untuk meningkatkan pelayanannya khususnya pelayanan kefarmasian.

Berdasarkan uraian di atas, peneliti tertarik untuk melakukan penelitian tentang pengaruh kepuasan pasien terhadap kualitas pelayanan resep di apotek instalasi farmasi Badan Rumah Sakit Daerah Luwuk

\section{METODE PENELITIAN}

\section{Jenis Penelitian}

Jenis penelitian ini merupakan penelitian non eksperimental berupa penelitian analitik kuantitatif dengan instrument penelitian yang digunakan berupa kuesioner.

\section{Populasi dan Sampel}

Populasi dalam penelitian ini adalah seluruh pengunjung/pasien yang berkunjung untuk mendapatkan pengobatan di apotek Instalasi Farmasi.

Pengambilan sampel dilakukan dengan accidental sampling. Jumlah sampel diambil berdasarkan jumlah indikator penelitian dikalikan 5 yaitu 22 indikator x $5=110$ responden. Pengambilan sampel didasarkan pada criteria inklusi dan eksklusi sebagai berikut :

Yang termasuk criteria inklusi :

1. Pasien yang berumur $17-60$ tahun

2. Ditemui sedang menebus obat di Instalasi Farmasi.

Yang termasuk criteria ekslusi adalah :

1. Pasien yang sakit keras

2. Tidak bersedia menjadi responden 
Maharani et al./Galenika Journal of Pharmacy

\section{HASIL DAN PEMBAHASAN}

Tabel 1. Karakteristik Responden

\begin{tabular}{|c|c|}
\hline $\begin{array}{l}\text { Karakteristik } \\
\text { Responden }\end{array}$ & Frekuensi (\%) \\
\hline $\begin{array}{l}\text { 1. Jenis kelamin } \\
\text { Laki-laki } \\
\text { Perempuan }\end{array}$ & $\begin{array}{c}46(41,82) \\
64(58,2)\end{array}$ \\
\hline $\begin{array}{l}\text { 2. Umur } \\
\leq 20 \text { Tahun } \\
21 \quad-30 \text { tahun } \\
31-40 \text { Tahun } \\
41-50 \text { Tahun } \\
>50 \text { Tahun }\end{array}$ & $\begin{array}{c}8(7,3) \\
55(50) \\
32(30) \\
13(11,82) \\
2(1,82)\end{array}$ \\
\hline $\begin{array}{l}\text { 3. Pendidikan terakhir } \\
\text { responden } \\
\text { a. SD } \\
\text { b. SMP } \\
\text { c. SMA } \\
\text { d. Diploma } \\
\text { e. S1/S2 }\end{array}$ & $\begin{array}{c}0 \\
5(4,54) \\
52(47,3) \\
31(28,2) \\
22 \quad(20)\end{array}$ \\
\hline
\end{tabular}

4. Pekerjaan responden
a. PNS/TNI/POLRI
$21(19,1)$
b. Pelajar/mahasiswa
$5(4,5)$
c. Petani
$3(2,73)$
d. Wiraswasta
$46(41,82)$
e. Lainnya
$35(31,82)$

Tabel 2 Deskripsi Variabel Penelitian

\begin{tabular}{|c|c|c|c|c|c|}
\hline No & Indikator & $\begin{array}{c}\text { Jumlah } \\
\text { Responden }\end{array}$ & $\begin{array}{c}\text { Nilai Rata- } \\
\text { Rata } \\
\text { Kategori }\end{array}$ & Interpretasi & $\begin{array}{c}\text { Tingkat } \\
\text { Kepuasan } \\
(\%)\end{array}$ \\
\hline 1 & Kecukupan tempat duduk & 110 & 3,95 & Baik & 62,73 \\
\hline 2 & Kelengkapan obat & 110 & 3,85 & Cukup Baik & 56,4 \\
\hline 3 & $\begin{array}{l}\text { Petugasberpenampilanrapi\&berpakaianseragam } \\
\text { Kebersihan ruang tunggu }\end{array}$ & 110 & 4,02 & Baik & 70,9 \\
\hline 4 & & 110 & 4,05 & Baik & 69,1 \\
\hline 5 & $\begin{array}{l}\text { Bersikap simpatik dan mampu memberikan } \\
\text { ketenangan terhadap keluhan pasien }\end{array}$ & 110 & 4,01 & Baik & 65,5 \\
\hline 6 & Resep dikerjakan tepat waktu (<30 menit) & 110 & 4,1 & Baik & 67,3 \\
\hline 7 & $\begin{array}{l}\text { Memberikan informasi obat yang mudah } \\
\text { dimengerti pasien }\end{array}$ & 110 & 4,2 & Cukup Baik & 55,5 \\
\hline 8 & $\begin{array}{l}\text { Petugas apotek selalu bersikap sopan kepada } \\
\text { pasien }\end{array}$ & 110 & 3,96 & Baik & 60 \\
\hline 9 & Petugas bersifat jujur dan dipercaya & 110 & 3,92 & Baik & 62,73 \\
\hline 10 & $\begin{array}{l}\text { Petugas apotek berpengetahuan luas sehingga } \\
\text { dapat menjawab pertanyaan pasien }\end{array}$ & 110 & 4,04 & Baik & 65,5 \\
\hline
\end{tabular}




\begin{tabular}{|c|c|c|c|c|c|}
\hline No & Indikator & $\begin{array}{c}\text { Jumlah } \\
\text { Responden }\end{array}$ & $\begin{array}{c}\text { Nilai Rata- } \\
\text { Rata } \\
\text { Kategori }\end{array}$ & Interpretasi & $\begin{array}{c}\text { Tingkat } \\
\text { Kepuasan } \\
(\%)\end{array}$ \\
\hline 11 & $\begin{array}{l}\text { Apoteker melakukan eyes contact langsung } \\
\text { dengan pasien }\end{array}$ & 110 & 4,02 & Baik & 65,5 \\
\hline 12 & $\begin{array}{l}\text { Petugas apotek melayani dengan cepat dan } \\
\text { segera }\end{array}$ & 110 & 3,99 & Baik & 73,64 \\
\hline 13 & Petugasselaluadadiruangpenerimaanresep & 110 & 3,97 & Cukup Baik & 54,55 \\
\hline 14 & $\begin{array}{l}\text { Petugas apotek dengan cepat memahami } \\
\text { kebutuhan pasien }\end{array}$ & 110 & 3,95 & Baik & 63,64 \\
\hline 15 & Apotek beroperasi setiap hari selama 24 jam & 110 & 4,15 & Baik & 66,4 \\
\hline 16 & $\begin{array}{l}\text { Petugas apotek memahami kebutuhan spesifik } \\
\text { pasien }\end{array}$ & 110 & 3,89 & Baik & 60 \\
\hline 17 & Petugas tidak membeda-bedakan pasien & 110 & 3,97 & Cukup Baik & 55,5 \\
\hline 18 & $\begin{array}{l}\text { Bagaimana aspek bukti langsung (tangibles) } \\
\text { menurut anda }\end{array}$ & 110 & 3,95 & Cukup Puas & 57,3 \\
\hline 19 & $\begin{array}{l}\text { Bagaimana aspek kehandalan (reliability) } \\
\text { menurut anda }\end{array}$ & 110 & 3,94 & Puas & 71,82 \\
\hline 20 & $\begin{array}{l}\text { Bagaimana aspek jaminan(Assurance) } \\
\text { menurut anda }\end{array}$ & 110 & 3,98 & Cukup Puas & 58,2 \\
\hline 21 & $\begin{array}{l}\text { Bagaimana aspek tanggapan(responsiveness) } \\
\text { menurut anda }\end{array}$ & 110 & 3,95 & Puas & 67,3 \\
\hline 22 & $\begin{array}{l}\text { Bagaimana aspek empati (emphaty) menurut } \\
\text { anda }\end{array}$ & 110 & 3,97 & Puas & 62,73 \\
\hline
\end{tabular}

Tabel 3.Hasil Uji Regresi Linear Berganda

Tabel 5.Hasil Uji F (Uji Simultan)

\begin{tabular}{cccc}
\hline Variabel & $\begin{array}{c}\text { B } \\
\text { (Koefisien } \\
\text { Regresi) }\end{array}$ & T & Sig \\
\hline Constant & 0,360 & 0,853 & 0,396 \\
Bukti & 0,477 & 5,610 & 0,000 \\
Langsung & & & \\
Kehandalan & 0,430 & 4,991 & 0,000 \\
Jaminan & 0,242 & 2,900 & 0,005 \\
$\quad$ Daya & $-0,136$ & $-1,617$ & 0,109 \\
Tanggap & & & \\
Empati & $-0,133$ & $-1,384$ & 0,169 \\
\hline
\end{tabular}

\begin{tabular}{lccc}
\hline \multicolumn{1}{c}{ Variabel } & $\begin{array}{c}\text { Jumlah } \\
\text { Responden }\end{array}$ & $\%$ & Signifikan \\
\hline Bukti & & & \\
$\begin{array}{l}\text { Langsung } \\
\text { Kehandalan }\end{array}$ & & & \\
Jaminan & 110 & $5 \%$ & 0,000 \\
$\begin{array}{l}\text { Daya } \\
\text { Tanggap }\end{array}$ & & & \\
Empati & & & \\
\hline
\end{tabular}

Tabel 4. Hasil uji Parsial (uji t)

\begin{tabular}{cccc}
\hline Variabel & $\begin{array}{c}\text { Jumlah } \\
\text { Responden }\end{array}$ & $\%$ & $\begin{array}{c}\text { Probabilitas } \\
\text { Signifikan }\end{array}$ \\
\hline Bukti & & & 0,000 \\
Langsung & & & 0,000 \\
Kehandalan & & $5 \%$ & 0,005 \\
Jaminan & 110 & $5 \%$ & 0,109 \\
Daya & & & 0,169 \\
Tanggap & & & \\
Empati & & & \\
\hline
\end{tabular}

Tabel 6.Hasil Uji Koefisien Determinasi

\begin{tabular}{cccc}
\hline Variabel & $\begin{array}{c}\text { Jumlah } \\
\text { Responden }\end{array}$ & $\begin{array}{c}\mathbf{p} \\
(\text { Value }) \\
\mathbf{R} \\
\text { Square }\end{array}$ & $\begin{array}{c}\text { \% } \\
\text { Kepuasan }\end{array}$ \\
\hline Bukti & & & \\
Langsung & & & \\
Kehandalan & & & \\
Jaminan & 110 & 0,482 & $48,2 \%$ \\
Daya & & & \\
Tanggap & & & \\
Empati & & & \\
\hline
\end{tabular}


Karakteristik responden pada tabel 1 menunjukkan bahwa responden dengan jenis kelamin perempuan sebanyak 64 orang $(58.2 \%)$ lebih banyak dari pada responden pria 46 orang (41.82\%). Subyek penelitian berdasarkan usia diperoleh nilai tertinggi pada kisaran usia 21-30 tahun sebanyak 55 responden $(50 \%)$ dan yang terendah usia $>50$ tahun $(1,82 \%)$. Hal ini dapat dikatakan bahwa sebagian besar pasien yang menebus resep di apotek instalasi farmasi banyak didominasi oleh pasien yang berumur produktif. Pendidikan responden menunjukkan bahwa pendidikan responden terbesar SMA yaitu 52 responden $(47.3 \%)$ dan pendidikan responden terendah SMP yaitu 5 responden $(4.54 \%)$. Hal ini menunjukkan bahwa makin tinggi pendidikan seseorang makin lebih peduli kepada kesehatannya. Selanjutnya pekerjaan responden yaitu 46 responden $(41.82 \%)$ bekerja sebagai wiraswasta, 21 responden $(19,1 \%)$ sebagai PNS/TNI/POLRI, pelajar atau mahasiswa sebanyak 5 responden $(4,5 \%)$, petani yaitu 3 responden $(2,73 \%)$, serta lainnya berjumlah 35 responden $(31,82 \%)$. Hal ini kemungkinan disebabkan olehpekerjaan yang menumpuk, stres, dan kurangnya gerakan badan dalam bekerja sehingga kondisi ini menyebabkan mereka mudah menderita suatu penyakit.

\section{Analisis Pengaruh Kepuasan Pasien}

\section{Hasil Analisis Regresi Linear Berganda}

Nilai konstanta kepuasan pasien sebesar 0,360 menunjukkan bahwa semakin meningkat pelayanan diberikan akan berpengaruh terhadap kepuasan pasien. Nilai koefisien regresi terendah terdapat pada variable responsiveness yaitu 0,136 diikuti oleh variable emphaty $-0,133$, variabel tangible 0,477 , dan variabel reliability nilai koefisien regresi yaitu 0,430 , serta nilai koefisien regresi tertinggi yaitu pada variabel assurance sebesar 0,242. Berdasarkan data tersebut menunjukkan bahwa terdapat dua variabel yang memiliki nilai negative yaitu variable responsiveness dan emphaty sehingga dapat disimpulkan bahwa setiap terjadi penurunan variable maka secara negative akan mengakibatkan kepuasan pasien meningkat, sebaliknya jika terjadi peningkatan variabel maka secara positif akan mengakibatkan penurunan kepuasan pasien. Data pada tabel 2 menunjukkan bahwa nilai rata-rata tertinggi pada variabel reliability, indikator 7 yaitu petugas memberikan informasi obat yang mudah dimengerti oleh pasien dengan nilai rata-rata sebesar 4,2. Hal ini menunjukkan bahwa kesadaran pasien untuk mendapat informasi mengenai obat yang digunakan sudah semakin tinggi, sehingga pelayanan resep di instalasi farmasi juga dituntut bisa memberikan informasi yang jelas mengenai pelayanan informasi obat. Menurut Trimurthy (2009), pelayanan informasi obat yang diberikan tidak harus ilmiah yang terpenting penerima mudah mengerti, memahami, dan menerima informasi yang dibutuhkan.

Indikator kualitas pelayanan resep yang memiliki nilai rata-rata terendah yaitu kelengkapan obat sebesar 3,85. Hal ini menunjukkan bahwa ketersediaan obat-obat di apotek masih kurang lengkap, sehingga pasien harus membutuhkan biaya tambahan untuk pergi menebus obat di luar apotek rumah sakit. Hal ini berbeda dengan penelitian yang dilakukan oleh (Manurung,2010) yang menyatakan bahwa ketersediaan obat diukur berdasarkan petugas memberikan solusi bila obat yang diminta pasien kosong dan obat yang diberikan di apotek ini kualitasnya terjamin. Hasil penelitiannya terhadap ketersediaan obat, jumlah obat lengkap lebih banyak $(59,9 \%)$ daripada jumlah obat yang tidak lengkap $(43,1 \%)$, artinya kesadaran apotek di instalasi farmasi mengenai ketersediaan obat merupakan faktor utama dalam menghadapi persaingan dengan apotek sekitarnya. Persediaan obat-obatan harus disesuaikan dengan besarnya kebutuhan masyarakat sekitar karena persediaan obat-obatan yang tidak lancer akan menghambat pelayanan kesehatan (Fakhriadi, 2011).

Indikator lain yang memiliki nilai terendah dengan interpretasi cukup baik adalah petugas apotek memahami kebutuhan spesifik pasien dengan nilai rata-rata kategori sebesar 3,89 , petugas bersifat jujur dan dipercaya yaitu 3,92 , petugas selalu ada diruang penerimaan resep 3,97, dan petugas tidak membeda-bedakan pasien 3,97. Hasil ini menunjukkan bahwa indicator kualitas pelayanan resep di apotek instalasi farmasi BRSD Luwuk masih belum dilakukan secara optimal. Sedangkan untuk indikator yang memiliki nilai rata-rata tertinggi 
dengan interpretasi baik yaitu apotek beroperasi setiap hari selama 24 jam sebesar 4,15 , resep dikerjakan tepat waktu ( $<30$ menit) 4,1 , kebersihan ruang tunggu 4,05 , petugas apotek berpengetahuan luas sehingga dapat menjawab pertanyaan pasien 4,04 , petugas berpenampilan rapi \& berpakaian seragam 4,02, apoteker melakukan eyes contact langsung dengan pasien 4,02, serta bersikap simpatik dan mampu memberikan ketenangan terhadap keluhan pasien 4,01. Dari data diatas menunjukkan bahwa kualitas pelayanan resep di apotek instalasi farmasi BRSD Luwuk dinilai baik.

\section{Hasil Uji Parsial (Uji t)}

Data pada tabel 4 menunjukkan bahwa terdapat dua variabel yang memiliki nilai signifikan > 0,05 yaitu variabel responsiveness dan empathy. Hasil yang diperoleh pada variabel responsiveness sebesar 0,109 dan empathy sebesar 0,169, hal ini dapat disimpulkan bahwa secara stastistik variable responsiveness dan empathy tidak berpengaruh signifikan terhadap kepuasan pasien, sedangkan nilai signifikan pada variabel tangible yaitu 0,000, reliability 0,000, dan assurance 0,005 menunjukkan adanya pengaruh yang signifikan terhadap kepuasan pasien, dimana nilai probabilitas $t$ sig $<0,05$. Hal ini sejalan dengan penelitian yang dilakukan oleh (Gery Leonard, 2012) yang menyatakan bahwa dari hasil penelitiannya, variable tangible, reliability, assurance berpengaruh signifikan terhadap kepuasan pasien, sedangkan variable responsiveness dan empathy tidak berpengaruh signifikan terhadap kepuasan pasien.

\section{Hasil Uji F (Simultan)}

Berdasarkan tabel 5 menunjukkan pengujian stastistik dengan menggunakan uji $\mathrm{F}$, dimana tingkat signifikan yang diperoleh lebih kecil yakni sebesar 0,000 dari standar signifikan yakni $5 \%$ atau 0,05 , maka dapat disimpulkan bahwa variabel independen yang terdiri dari tangible, reliability, assurance, responsiveness dan empathy berpengaruh signifikan terhadap kepuasan pasien. Hasil yang sama juga dilakukan oleh (Gery Leonard, 2012) dimana tingkat signifikan yang diperoleh lebih kecil yakni sebesar 0,000 dari standar signifikan yakni $5 \%$ atau 0,05 .

\section{Hasil Koefisien Determinasi}

Hasil perhitungan koefisien determinasi diperoleh nilai $\mathrm{r}$ square sebesar 0,482 . Hal ini menunjukkan nilai $\mathrm{r}$ square sebesar 0,482 pada variabel tangible, reliability, assurance, responsiveneess, dan empathy mampu menjelaskan kepuasan pasien sebesar 48,2\%, sementara sisanya sebesar $51,8 \%$ dijelaskan oleh faktor lain yang tidak dimasukkan dalam penelitian ini. Menurut ghozali 2005, nilai koefisien determinasi adalah 0 sampai 1 , jika nilai $r$ square mendekati 1 berarti variabel independent memberikan hampir semua informasi yang dibutuhkan untuk memprediksi variabel dependent (kepuasan pasien), selanjutnya nilai $r$ square yang kecil berarti kemampuan variabel independent dalam menjelaskan variabel dependent sangat terbatas. Dengan demikian dapat disimpulkan bahwa kepuasan pasien terhadap kualitas pelayanan resep di apotek instalasi farmasi dirasakan masih kurang baik sehingga perlu dilakukan penambahan atau perbaikan kualitas pelayanannya agar kepuasan pasien semakin bertambah.

\section{DAFTAR PUSTAKA}

Aditama, T,Y. (2002). Manajemen Administrasi Rumah Sakit, Edisi kedua, UI Press, Jakarta.

Adhiatma, A. (2001). Analisis Kepuasan Konsumen Terhadap Kualitas Pelayanan Jasa Kesehatan Di Rumah Sakit Ibu dan Anak Di Semarang, 2(2), 67-76.

Arikunto, S. (2002). Prosedur Penelitian Suatu Pendekatan Praktek, Edisi Revisi kelima, Rineka Cipta, Yogyakarta.

Azwar, A. (1996). Pengantar Administrasi Kesehatan, Bina Rupa Aksara, Jakarta. 
Fakhriadi, A. (2011). Analisis PengelolaanObat Di Instalasi Farmasi RSUP H. Adam Malik Medan Tahun 2006. Skripsi FakultasFarmasi USU, Medan.

Ghozali, I. (2005). Aplikasi Analisis Multivariat dengan program SPSS, Badan Penerbit Universitas Diponegoro, Semarang.

Leonard, G. (2012). Analisis Pengaruh Kualitas Layanan Terhadap Kepuasan Pasien Pada Rumah Sakit Elim Kab.TorajaUtara, Universitas Hasanuddin. Makassar.

Manurung, L. (2002). Analisis Hubungan Tingkat Kepuasan Pasien Rawat Jalan Terhadap Pelayanan Instalasi Farmasi
Dengan Minat Pasien Menebus Kembali Resep Obat di Instalasi Farmasi RSUD Budhi Asih Tahun 2010, Tesis ,UI, Jakarta.

Siregar, C.J.P. (2003). Farmasi Rumah Sakit :Teori dan Penerapan, Penerbit Buku Kedokteran, EGC, Jakarta.

Trimurthy, P. (2009). Analisis Hubungan Persepsi Pasien Tentang Mutu Pelayanan Dengan Minat Pemanfaatan Ulang Palayanan Rawat Jalan Puskesmas Pandanaran Kota Semarang. Tesis Universitas Diponegoro, Semarang. 